Article

\title{
Effect of Intermetallic Compound Layer on Peel Strength and Crack Propagation Behavior in $\mathrm{Cu} / \mathrm{Al} / \mathrm{Cu}$ Clad Composites
}

\author{
Yong Keun Kim and Sun Ig Hong *(1) \\ Department of Materials Science and Engineering, Chungnam National University, Daejeon 305-764, Korea; \\ yongkeunkim84@gmail.com \\ * Correspondence: sihong@cnu.ac.kr
}

Received: 8 October 2019; Accepted: 25 October 2019; Published: 27 October 2019

\begin{abstract}
The effects of interfacial modification in tri-layered $\mathrm{Cu} / \mathrm{Al} / \mathrm{Cu}$ composites by heat treatment on interface stability and crack propagation were investigated. In order to investigate the crack path during the peel test, the intermetallic compound layer with the propagating crack was examined using electron backscatter diffraction (EBSD) analyses. The increase of peel strength from 7.8 to $9.1 \mathrm{~N} / \mathrm{mm}$ in the tri-layered $\mathrm{Cu} / \mathrm{Al} / \mathrm{Cu}$ composite in the presence of thin discontinuous intermetallic compounds with heat treatment at $200-300{ }^{\circ} \mathrm{C}$ was accompanied by the increase of electrical conductivity from 65.3\% IACS (International Annealed Copper Standard) to 66.8\% IACS. Continuous intermetallic layers consisting of $\mathrm{Al}_{2} \mathrm{Cu}, \mathrm{AlCu}$, and $\mathrm{Al}_{4} \mathrm{Cu}_{9}$ were found in $\mathrm{Cu} / \mathrm{Al} / \mathrm{Cu}$ heat-treated at temperatures above $350{ }^{\circ} \mathrm{C}$ and its thickness increased rapidly and reached up to $35.2 \mu \mathrm{m}$ at $500{ }^{\circ} \mathrm{C}$. The peel strength drastically decreased to $5.75 \mathrm{~N} / \mathrm{mm}$ after heat treatment at $400^{\circ} \mathrm{C}$, and it gradually increased as the heat treatment temperature was increased to $450{ }^{\circ} \mathrm{C}(5.91 \mathrm{~N} / \mathrm{mm})$ and $500{ }^{\circ} \mathrm{C}(6.16 \mathrm{~N} / \mathrm{mm})$. The increased peel strengths after heat treatment at 450 and $500^{\circ} \mathrm{C}$ were accompanied by pronounced serrations of the peel strength-displacement curves. The amplitude of serration increased substantially with increasing annealing temperature from 400 to $500{ }^{\circ} \mathrm{C}$. The major crack along the interface propagated, mostly along the $\mathrm{Al}_{2} \mathrm{Cu} / \mathrm{AlCu}$ boundary with some inclined cracks, propagated through the $\mathrm{AlCu}$ and $\mathrm{Al}_{4} \mathrm{Cu}_{9}$ intermetallic compound layers. The repetition of crack propagation along the interface and crack deflection through the intermetallic layer as an inclined crack induced the serrated surface on the peeled-off $\mathrm{Cu}$ plate, enhancing the interface toughening.
\end{abstract}

Keywords: composite; crack propagation; intermetallic compound; interface; peel strength

\section{Introduction}

A large body of research has recently been conducted to develop ways to reduce the vehicle weight in automobile industry [1,2]. The closely aligned electronics and communications industries also share the common goal of weight lightening and are focused on developing light products with high performance. Reducing weight can be accomplished either by replacing conventional materials with new ones or by improving the properties of conventional materials. Many recent studies have been devoted to cladding, which involves joining different materials through mechanical or thermomechanical processing [3,4]. Cladding by joining various metals allows for combination of new properties that may not be possible in monolithic metals and alloys, such as combination of corrosion resistance, specific strength [5], surface properties, and reduced weight. Clad composites can be selected or designed based on the properties required for application. Representative cladding matrix materials include titanium [6,7], stainless steel [8,9], carbon steel, magnesium [10,11], aluminum (Al) [12-14], and copper ( $\mathrm{Cu}$ [15-17]. Al and $\mathrm{Cu}$, nonferrous metals with excellent electric conductivity 
and corrosion resistance as well as attractive surfaces, are widely employed in various fields, including electric and electronic industries, automobile industry, aerospace industry, and architecture.

The material properties of Cu-based alloys [18] used for electrical or electronic applications are controlled by heat treatment, resulting in both high electrical and thermal conductivities and tensile strength [19]. However, $\mathrm{Cu}$ and $\mathrm{Cu}$ alloys are more expensive and have a higher specific weight than $\mathrm{Al}$ and $\mathrm{Al}$ alloys with lower conductivity. This increases maintenance or transportation costs, and the risk of failure increased due to their self-loading when they are in service for ground power lines or bus bars [16]. Al has excellent corrosion resistance, wear resistance, formability, good electrical conductivity (63\% IACS), and light weight. However, the applications of $\mathrm{Al}$ in electrical cables and bus bars, which require better conductivity and strength, are still limited. Given the individual advantages and limitations of the $\mathrm{Cu}$ and $\mathrm{Al}$, demand for $\mathrm{Cu} / \mathrm{Al}$ clad composites [14,20,21], which exhibit excellent electrical properties and specific strength, is steadily increasing. Once the stability and reliability of the clad composites and interfaces between these two metals have been secured, they may replace $\mathrm{Cu}$ because of advantages associated with weight and price competitiveness.

Among methods of fabricating clad composites include rolling [22,23], extrusion [24,25], explosive welding [26], laser cladding [27], and drawing, roll-cladding is most frequently employed, because it is easy, efficient, and less expensive in comparison with other cladding methods. In clad composites, insufficient interfacial bonding strength between joining metals may cause interfacial debonding and failure. Because the bonding strength of a clad composite is dependent on interfacial shear and surface deformation, which is influenced by the reduction ratio in the rolling process, a large reduction ratio higher than $50 \%$ is required to fabricate clad composites with high bond strength. Although $\mathrm{Al}$ and $\mathrm{Cu}$ metals have high formability, the fabrication of $\mathrm{Al} / \mathrm{Cu}$ clad composites with reliable electrical and mechanical properties is not easy because of the difference of deformation properties of two metals and the probable formation of brittle interfacial intermetallic compounds (IMCs). Clad composites bonded at low temperature can have incomplete bonding and exhibit a higher risk of interface debonding $[15,16]$. In contrast, processing clad composites at an elevated temperature produces brittle IMCs $\mathrm{Al}_{x} \mathrm{Cu}_{y}[25,28]$, which have an adverse effect on mechanical integrity and electrical performance.

Particularly in the presence of bonding defects and intermetallic layers/particles at the interface, electrical resistivity and accordingly electrical resistance heating may rise locally in electrical applications of $\mathrm{Cu} / \mathrm{Al}$ clad composites. This may cause a severe risk to stability and integrity of $\mathrm{Cu} / \mathrm{Al}$ composite parts and compartments because heat and sparks may result from bonding defects and intermetallic layers/particles. Therefore, increase of processing and service temperatures in $\mathrm{Cu} / \mathrm{Al}$ clad composites should be avoided. The objective of this work is to investigate the effects of IMC formation at the interfaces of roll-bonded $\mathrm{Cu} / \mathrm{Al} / \mathrm{Cu}$ clad composites by annealing up to $500{ }^{\circ} \mathrm{C}$ on the mechanical integrity and failure mechanism. The $\mathrm{Cu} / \mathrm{Al}$ bonding strengths before and after intermetallic formation were also measured by peel tests, and influence of intermetallic layer thickness on the bonding stress and peel strength were analyzed.

\section{Experimental Details}

The $\mathrm{Cu} / \mathrm{Al} / \mathrm{Cu}$ clad composites used for this study were fabricated by rolling stacked layers of an oxygen-free high-conductivity (OFHC) copper $(99.9 \%$ purity with $0.002 \% \mathrm{Zn}$ ) plate and a $1060 \mathrm{Al}$ plate of commercial purity $(99.5 \%$ purity with $0.05 \% \mathrm{Cu}, 0.20 \% \mathrm{Si}$, and $0.25 \% \mathrm{Fe}$ ). Stacked plates were rolled at a $65 \%$ reduction in thickness at room temperature in a single pass. The final thickness of $\mathrm{Cu} / \mathrm{Al} / \mathrm{Cu}$ clad composite was $2.0 \mathrm{~mm}$ with those of $\mathrm{Al}$ and $\mathrm{Cu}$ layers being $1.6 \mathrm{~mm}$ and $0.2 \mathrm{~mm}$, respectively. $\mathrm{Cu} / \mathrm{Al} / \mathrm{Cu}$ clad plates were annealed at temperatures from 200 to $500{ }^{\circ} \mathrm{C}$ for $3 \mathrm{~h}$ after cold roll-bonding. The $\mathrm{Al} / \mathrm{Cu}$ bonding strength at room temperature was measured by peel tests $[12,20]$ using a Universal Mechanical Testing System (US/SSTM, Fullerton, CA, USA). Peel tests were carried out at a crosshead speed of $1 \mathrm{~mm} / \mathrm{min}$ and 3 different experiments were conducted for each condition. The microstructures and integrity of interfaces of $\mathrm{Cu} / \mathrm{Al} / \mathrm{Cu}$ clad plates were examined by a stereoscopic microscope (SM, DAMISYSTEM, DS-Z-151, Daejon, Korea) and a scanning electron microscope (SEM, JEOL, JSM-7000F, 
Tokyo, Japan) equipped with electron backscatter diffraction (EBSD). In order to examine the structure and composition of thin interfacial intermetallic layers, energy-dispersive X-ray spectroscopy (EDS) and X-ray diffraction (BRUKERS, D8 DISCOVER, Coventry, UK) analyses were performed on the separated interfaces of peeled-off $\mathrm{Al}$ and $\mathrm{Cu}$ plates. The interfacial intermetallic regions with cracks were also observed using EBSD to investigate the crack path in the intermetallic layers.

\section{Results and Discussion}

\subsection{Characterization of Interface Layers}

Figure 1 displays backscattered electron (BSE) images of the interface layers of the $\mathrm{Cu} / \mathrm{Al} / \mathrm{Cu}$ clad composites heat-treated at $300{ }^{\circ} \mathrm{C}$ (Figure 1a), $400{ }^{\circ} \mathrm{C}$ (Figure 1b), $450{ }^{\circ} \mathrm{C}$ (Figure 1c), and $500{ }^{\circ} \mathrm{C}$ (Figure 1d) for 3 hours and EDS spectra (Figure 1e-g) at the positions marked with " $\mathrm{E}^{\prime \prime}$, " $\mathrm{F}^{\prime \prime}$, and " $G$ " in Figure 1d. No visible defect such as interface cracking or debonding were observed in the as-roll-bonded $\mathrm{Cu} / \mathrm{Al} / \mathrm{Cu}$ composite (not shown in Figure 1) and the heat-treated specimens (Figure 1a-d). The thickness of thin and discontinuous IMCs (indicate by the box marked with white dotted lines) was found to be $1.42 \pm 0.3 \mu \mathrm{m}$ at the $\mathrm{Cu} / \mathrm{Al}$ interface of the clad composite heat-treated at $300{ }^{\circ} \mathrm{C}$ (Figure 1a). A continuous reaction layer formed at the $\mathrm{Al} / \mathrm{Cu}$ interface was found in the specimens heat-treated at a temperature of $400{ }^{\circ} \mathrm{C}$ (Figure 1b) and higher (Figure 1c,d). The SEM image in Figure 1d shows that IMC layers consist of three phases. The atomic percentage of $\mathrm{Al}$ in the layer marked with "E" (in contact with $\mathrm{Al}$ ) was approximately twice as high as that of $\mathrm{Cu}$ (Figure 1e). The atomic percentage of $\mathrm{Al}$ was similar to that of $\mathrm{Cu}$ in the layer marked with "F" (Figure 1f) and the atomic percentage of $\mathrm{Cu}$ in the layer marked with " $\mathrm{G}$ " (in contact with $\mathrm{Cu}$ ) was twice as high as that of Al (Figure 1g).
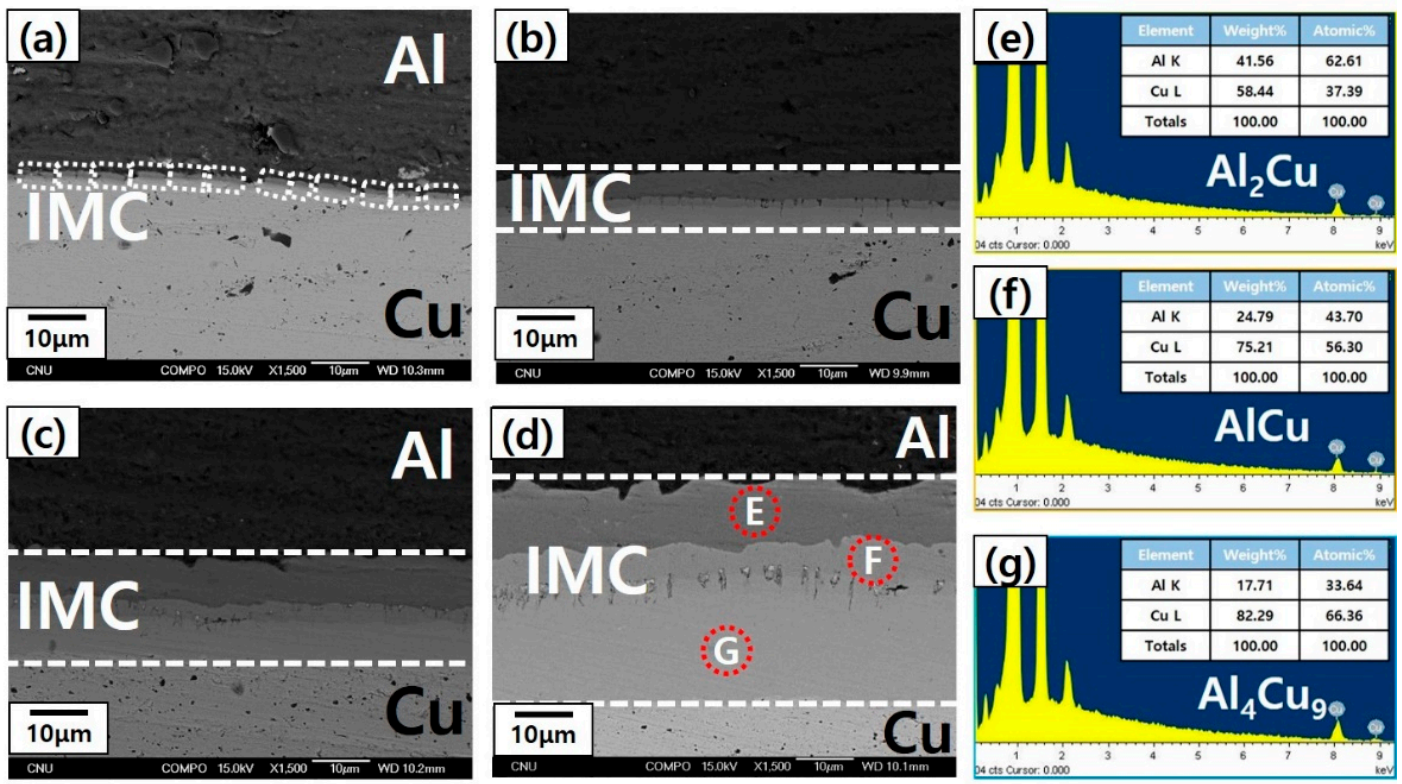

Figure 1. Backscattered electron (BSE) images of the interface layers of the $\mathrm{Cu} / \mathrm{Al} / \mathrm{Cu}$ clad composites heat-treated at $300^{\circ} \mathrm{C}(\mathbf{a}), 400{ }^{\circ} \mathrm{C}(\mathbf{b}), 450{ }^{\circ} \mathrm{C}(\mathbf{c})$, and $500{ }^{\circ} \mathrm{C}(\mathbf{d})$ for 3 hours; and EDS spectra (e-g) at the positions marked with " $\mathrm{E}^{\prime}$, " $\mathrm{F}$ ", and " $\mathrm{G}$ " in (d), respectively.

The XRD patterns from the bonding interfaces of $\mathrm{Al}$ (Figure 2a) and $\mathrm{Cu}$ (Figure 2b) plates after being detached from each other by a peel test, shown in Figure 2, were analyzed by referring to the Al-Cu phase diagram [29]. Figure 2a,b shows the XRD patterns of the as-roll-bonded specimen and specimens annealed at temperatures between 200 and $500{ }^{\circ} \mathrm{C}$. In addition to $\mathrm{Al}$ peaks from the $\mathrm{Al}$ surface and $\mathrm{Cu}$ peaks from the $\mathrm{Cu}$ surface shown in Figure 2a,b, peaks from $\mathrm{Al}_{2} \mathrm{Cu}, \mathrm{AlCu}$, and $\mathrm{Al}_{4} \mathrm{Cu}_{9}$ 
were observed, supporting that the E, F, and G IMC layers in Figure 1 are indeed $\mathrm{Al}_{2} \mathrm{Cu}, \mathrm{AlCu}$, and $\mathrm{Al}_{4} \mathrm{Cu}_{9}$, respectively. As shown in Figure $2 \mathrm{a}$, at the $\mathrm{Al}$ surface, the intensity of the $\mathrm{Al}$ peak $\left(2 \theta: 38.4^{\circ}\right)$ decreased and that of the $\mathrm{Al}_{2} \mathrm{Cu}$ peak $\left(2 \theta: 42.64^{\circ}\right)$ increased as the temperature increased from 400 to $500{ }^{\circ} \mathrm{C}$. At the detached $\mathrm{Cu}$ surface shown in Figure $2 \mathrm{~b}$, the intensity of the $\mathrm{Cu}$ peak $\left(2 \theta: 50.46^{\circ}\right.$ and $\left.74.12^{\circ}\right)$ decreased and that of the $\mathrm{Al}_{4} \mathrm{Cu}_{9}$ peak $\left(2 \theta: 44.12^{\circ}\right)$ increased as the temperature increased, suggesting the thickening of IMCs with increase of annealing temperature.

(a) Al side

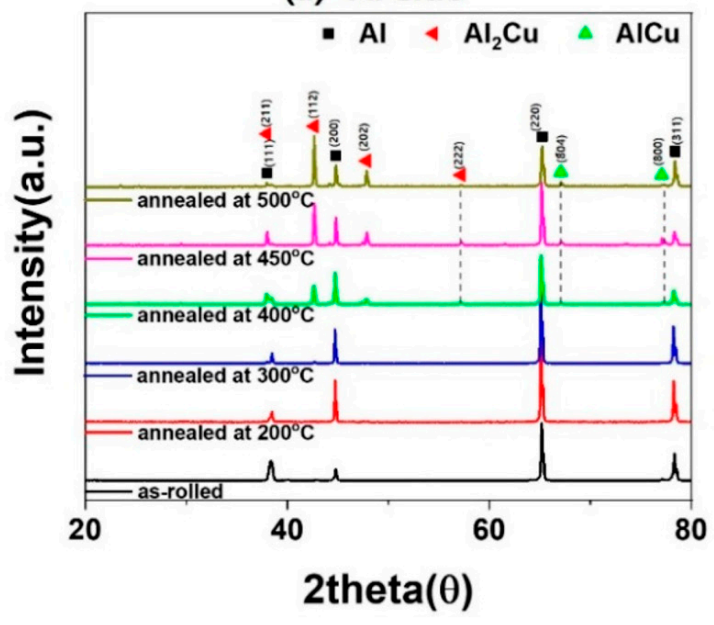

(b) Cu side

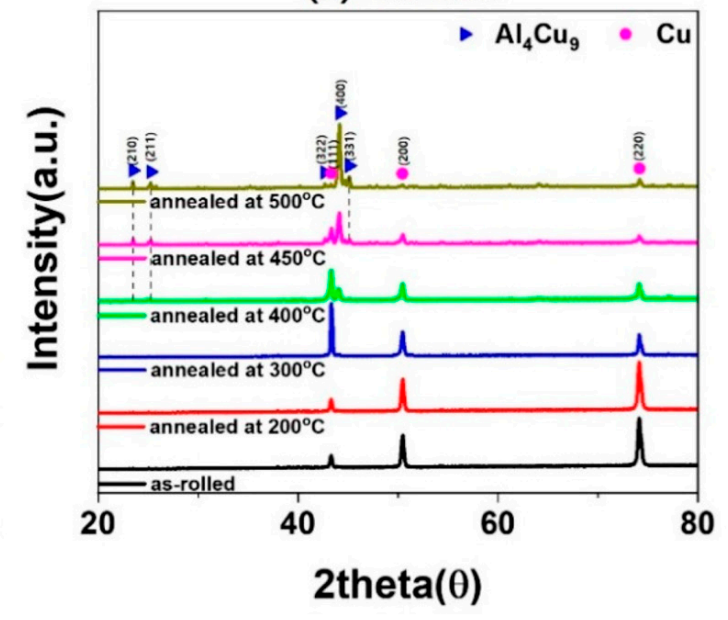

Figure 2. XRD patterns from separated interfaces of $\mathrm{Al}(\mathbf{a})$ and $\mathrm{Cu}(\mathbf{b})$ plates from as-rolled clad composites and those heat-treated at temperatures from 200 to $500{ }^{\circ} \mathrm{C}$.

Figure 3a shows the variation of the intermetallic layer thickness as a function of annealing temperature for $\mathrm{Cu} / \mathrm{Al} / \mathrm{Cu}$ clad specimens, and Figure $3 \mathrm{~b}$ shows the thickness ratios of the individual $\mathrm{Al}_{2} \mathrm{Cu}, \mathrm{AlCu}$, and $\mathrm{Al}_{4} \mathrm{Cu}_{9}$ intermetallic layers. In Figure 3a, the entire IMC layer thickness increased as the annealing temperature increased. $\mathrm{Al}_{2} \mathrm{Cu}$ and $\mathrm{AlCu}$ compound layers grew gradually with increasing heat treatment temperature. The $\mathrm{Al}_{4} \mathrm{Cu}_{9}$ layer thickness was smaller than that of $\mathrm{Al}_{2} \mathrm{Cu}$ at temperatures up to $400{ }^{\circ} \mathrm{C}$, but it increased rapidly as the temperature increased from 400 to $500{ }^{\circ} \mathrm{C}$. The ratios of the individual layers, shown in Figure $3 \mathrm{~b}$, indicated that the thickness ratio of the $\mathrm{Al}_{2} \mathrm{Cu}$ layer was the highest after heat treatment at $400{ }^{\circ} \mathrm{C}$, but its thickness ratio decreased and the thickness ratio of $\mathrm{Al}_{4} \mathrm{Cu}_{9}$ increased rapidly with increase of temperature above $400{ }^{\circ} \mathrm{C}$. The higher heat release involved in $\mathrm{Al}_{4} \mathrm{Cu}_{9}$ formation suggests that $\mathrm{Al}_{4} \mathrm{Cu}_{9}$ is more stable than $\mathrm{Al}_{2} \mathrm{Cu}$ and $\mathrm{AlCu}$. However, the activation energies of growth of $\mathrm{Al}_{4} \mathrm{Cu}_{9}(89.8 \mathrm{~kJ} / \mathrm{mol})$ and $\mathrm{AlCu}(84.6 \mathrm{~kJ} / \mathrm{mol})$ intermetallics are appreciably higher than those of $\mathrm{Al}_{2} \mathrm{Cu}(60.7 \mathrm{~kJ} / \mathrm{mol})$ [30]. The higher activation energy of growth for $\mathrm{Al}_{4} \mathrm{Cu}_{9}$ suggests a higher energy barrier of nucleation and growth of $\mathrm{Al}_{4} \mathrm{Cu}_{9}$, making the growth rate lower at low temperatures. However, the fraction of $\mathrm{Al}_{4} \mathrm{Cu}_{9}$ would increase rapidly with temperature because of its higher driving force (i.e., its higher heat release). The formation of $\mathrm{Al}_{2} \mathrm{Cu}$ is, therefore, favored at lower temperatures and the fraction of $\mathrm{Al}_{2} \mathrm{Cu}$ is higher than those of $\mathrm{Al}_{4} \mathrm{Cu}_{9}$, as shown in Figure $3 \mathrm{~b}$. The fraction of $\mathrm{Al}_{4} \mathrm{Cu}_{9}$ increased with the increase of temperature as the formation of $\mathrm{Al}_{4} \mathrm{Cu}_{9}$ became easier with increase of temperature because of its higher driving force. 

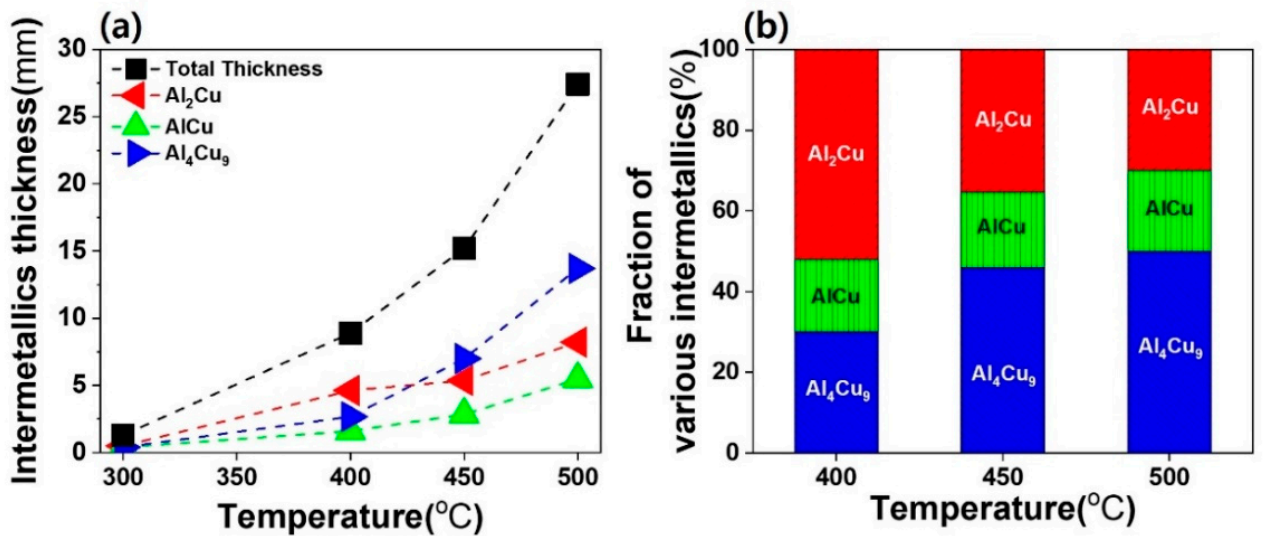

Figure 3. (a) Intermetallic compound (IMC) layer thickness of $\mathrm{Cu} / \mathrm{Al} / \mathrm{Cu}$ clad specimens as a function of heat treatment temperature; and (b) thickness ratios of $\mathrm{Al}_{2} \mathrm{Cu}, \mathrm{AlCu}$, and $\mathrm{Al}_{4} \mathrm{Cu}_{9}$ intermetallic layers as a function of heat treatment temperature.

Figure 4 shows the variations of the electrical conductivity and the total intermetallic layer as a function of annealing temperature. As stated, discontinuous IMC layers were observed at the $\mathrm{Cu} / \mathrm{Al}$ interface after heat treatment at a temperature range of $200-300{ }^{\circ} \mathrm{C}$. On the other hand, a continuous compound layer was formed at the $\mathrm{Cu} / \mathrm{Al}$ interface after heat treatment at 400,450 , and $500{ }^{\circ} \mathrm{C}$, as shown in Figure 1. Kim and Hong [12] reported that the interface layer of the as-roll-bonded $\mathrm{Cu} / \mathrm{Al} / \mathrm{Cu}$ composite consists of a metallurgically bonded region, a mechanochemically reacted thin IMC region, and a weakly bonded region. They further suggested that the area fractions of metallurgically bonded region, intermetallic region, and weakly bonded region are $59.6 \%, 14.8 \%$, and $25.6 \%$, respectively, just after roll-bonding. The increase of the conductivity after heat treatment from 200 to $300{ }^{\circ} \mathrm{C}$ was thought to be due to the enhanced interface diffusion bonding of the weakly bonded region. Since the thickness of intermetallic layer increased with temperature, the conductivity decreased gradually after heat treatment at temperatures above $300^{\circ} \mathrm{C}$ and dropped rapidly because of the rapid growth of intermetallic layer at temperatures above $400{ }^{\circ} \mathrm{C}$.

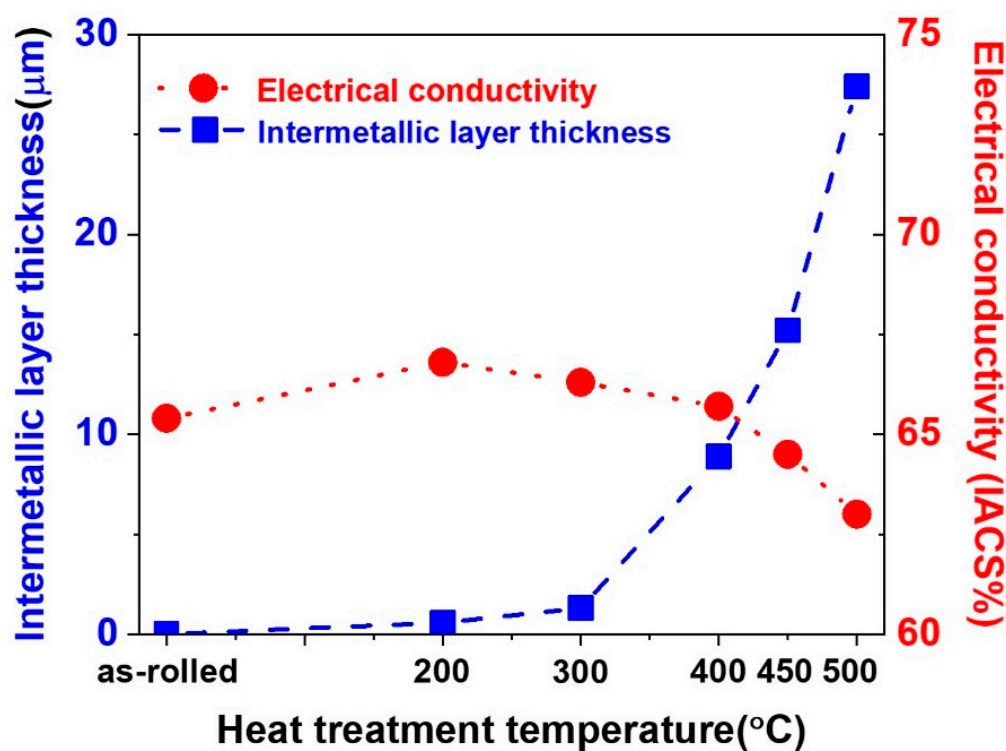

Figure 4. Electrical conductivity and total intermetallic layer thickness as a function of heat treatment temperature. 


\subsection{Peel Strength during Crack Propagation along Intermetallic Layers}

Figure 5a shows the peel strength-displacement curve of the as-rolled specimen and those heat-treated at a temperature range from 200 to $500{ }^{\circ} \mathrm{C}$. It is noted that peel strengths of the $\mathrm{Cu} / \mathrm{Al} / \mathrm{Cu}$ clad annealed at 200 and $300{ }^{\circ} \mathrm{C}$ were higher than that of the as-rolled specimen. Annealing at 200 and $300{ }^{\circ} \mathrm{C}$ apparently increased the interfacial bonding strength, despite the presence of discontinuous IMC particles/layers at the interface. The thin IMC layer formed at $\mathrm{Cu} / \mathrm{Al}$ interfaces did not aggravate the interface strength, but it strengthened the interface strength substantially. This observation is compatible with the report that IMC layer with a thickness less than $5 \mu \mathrm{m}$ is not detrimental to the interface strength $[6,12]$. Figure $5 b$ shows an expanded view of peel strength-displacement curves along the $y$-axis for the $\mathrm{Cu} / \mathrm{Al} / \mathrm{Cu}$ clad composites heat-treated at 400,450 , and $500{ }^{\circ} \mathrm{C}$. The peel strength decreased noticeably after annealing at $400{ }^{\circ} \mathrm{C}$ because of the thick brittle intermetallic layers. One of the most interesting observations is that stress levels of the curves increased as the heat treatment annealing temperature further increased from 400 to $500{ }^{\circ} \mathrm{C}$. The increased peel strength levels of $\mathrm{Cu} / \mathrm{Al} / \mathrm{Cu}$ clad composites annealed at 450 and $500{ }^{\circ} \mathrm{C}$, compared to that of specimens heat-treated at $400{ }^{\circ} \mathrm{C}$, were accompanied by pronounced serrations of the curves. The amplitude of serration increased substantially with increase of annealing temperature from 400 to $500^{\circ} \mathrm{C}$. Figure $5 \mathrm{c}$ exhibits the variation of the average peel strength as a function of annealing temperature. It is apparent that the average peel strength increased from that of the as-roll-bonded $\mathrm{Cu} / \mathrm{Al} / \mathrm{Cu}$ composite $(7.8 \mathrm{~N} / \mathrm{mm})$ to 9.0-9.2 N/mm after heat-treatment at a temperature increased from 200 to $300{ }^{\circ} \mathrm{C}$. Figure $5 \mathrm{c}$ clearly shows that the peel strength drastically decreased to $5.75 \mathrm{~N} / \mathrm{mm}$ in the specimen heat-treated at $400{ }^{\circ} \mathrm{C}$, and it gradually increased as the heat treatment temperature was increased to $450{ }^{\circ} \mathrm{C}(5.91 \mathrm{~N} / \mathrm{mm})$ and $500{ }^{\circ} \mathrm{C}(6.16 \mathrm{~N} / \mathrm{mm})$.

\subsection{Crack Propagation and Crack Deflection in Intermetallic Layers}

Figure 6 shows the stereoscopic microscopic images obtained during the peel testing at displacements of $0.1 \mathrm{~mm}$ (Figure 6a1-d1), $0.2 \mathrm{~mm}$ (Figure 6a2-d2), and $0.3 \mathrm{~mm}$ (Figure 6a3-d3), in the order of the as-rolled specimen (Figure 6a-a3) and the specimens that were heat-treated at $400{ }^{\circ} \mathrm{C}$ (Figure $6 \mathrm{~b}-\mathrm{b} 3$ ), $450{ }^{\circ} \mathrm{C}$ (Figure $6 \mathrm{c}-\mathrm{c} 3$ ), and $50{ }^{\circ} \mathrm{C}$ (Figure $6 \mathrm{~d}-\mathrm{d} 3$ ). The images of the as-rolled $\mathrm{Cu} / \mathrm{Al} / \mathrm{Cu}$ clad composite (Figure 6a-a3) show cracking and peeling along the $\mathrm{Cu} / \mathrm{Al}$ interface. It appears that the plastically deformed zone developed in the near-interface regions of the thinner $\mathrm{Cu}$ plate and the thicker Al base plate in the process of interface separation during the peel test. The plastically deformed zone suggests the excellent bonding between $\mathrm{Cu}$ and $\mathrm{Al}$ and the development of the plastic deformation zone also contributes to the increase of the peel strength.

The images of $\mathrm{Cu} / \mathrm{Al} / \mathrm{Cu}$ clad composite heat-treated at $400{ }^{\circ} \mathrm{C}$ (Figure $6 \mathrm{~b} 1, \mathrm{~b} 2$ ) show that the vertical cracks were formed within the thin interface IMC layer in the direction perpendicular to the bonding surface with a length about $200 \mu \mathrm{m}$ (indicatd by a box marked with red dotted lines) in front of the tip of the propagating interface crack. The images of the specimen that was heat-treated at $450{ }^{\circ} \mathrm{C}$ (Figure $6 \mathrm{c} 1, \mathrm{c} 2$ ) show that vertical cracks formed in the direction perpendicular to the intermetallic layer (indicated by a circle marked with red dotted lines) as in the specimen that was heat-treated at $450{ }^{\circ} \mathrm{C}$. Figure $6 \mathrm{c} 3$ shows that the separated intermetallic layer with the vertical cracks was attached to the separated $\mathrm{Cu}$ layer. It appears that the vertical crack was formed because of the bending stress developed along the peeled-off $\mathrm{Cu}$ plate and the separated layer surface appeared to be serrated because of vertical cracks. On the other hand, in the thin intermetallic layer consisting of mostly $\mathrm{Al}_{2} \mathrm{Cu}$ that is attached to $\mathrm{Al}$ layer, no vertical cracks developed. Images of the specimen that was heat-treated at $500{ }^{\circ} \mathrm{C}$ show the thicker IMC layer (Figure $6 \mathrm{~d}-\mathrm{d} 3$ ). Figure $6 \mathrm{~d} 2, \mathrm{~d} 3$ also exhibits the separated intermetallic layer with the larger vertical cracks were attached to the separated Cu layer and the separated surface appeared jaggy because of more pronounced and deep vertical cracks. Videos showing the interface cracking behaviors during the peel tests of as-roll-bonded $\mathrm{Cu} / \mathrm{Al} / \mathrm{Cu}$ composite clad and those heat-treated at 400,450 , and $500^{\circ} \mathrm{C}$ are provided as supplementary videos S1-S4 (Supplementary Materials). 

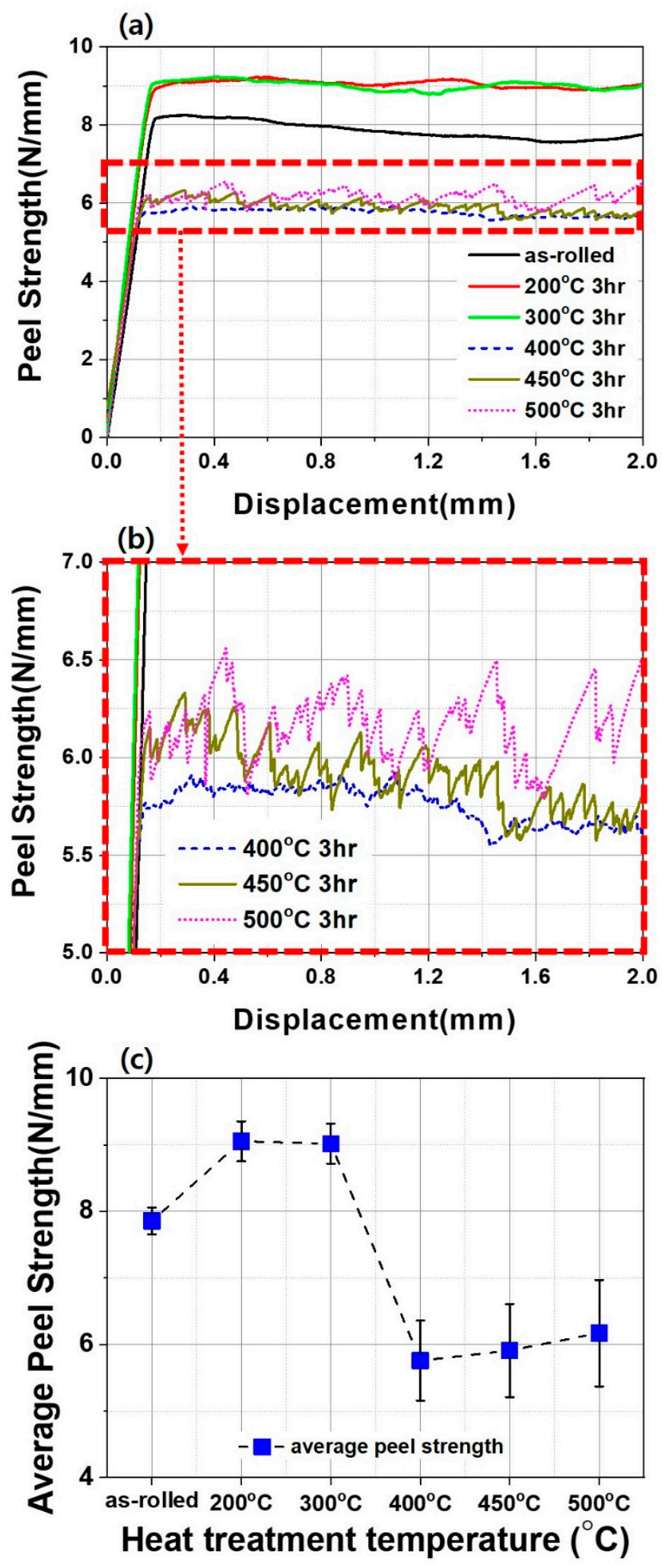

Figure 5. (a) Peel strength-displacement relationship of the as-rolled specimen and those heat-treated at a temperature range from 200 to $500{ }^{\circ} \mathrm{C}$; (b) magnified view of curves enclosed with a square marked with red dotted lines in (a); and (c) average peel strength as a function of heat treatment temperature. 


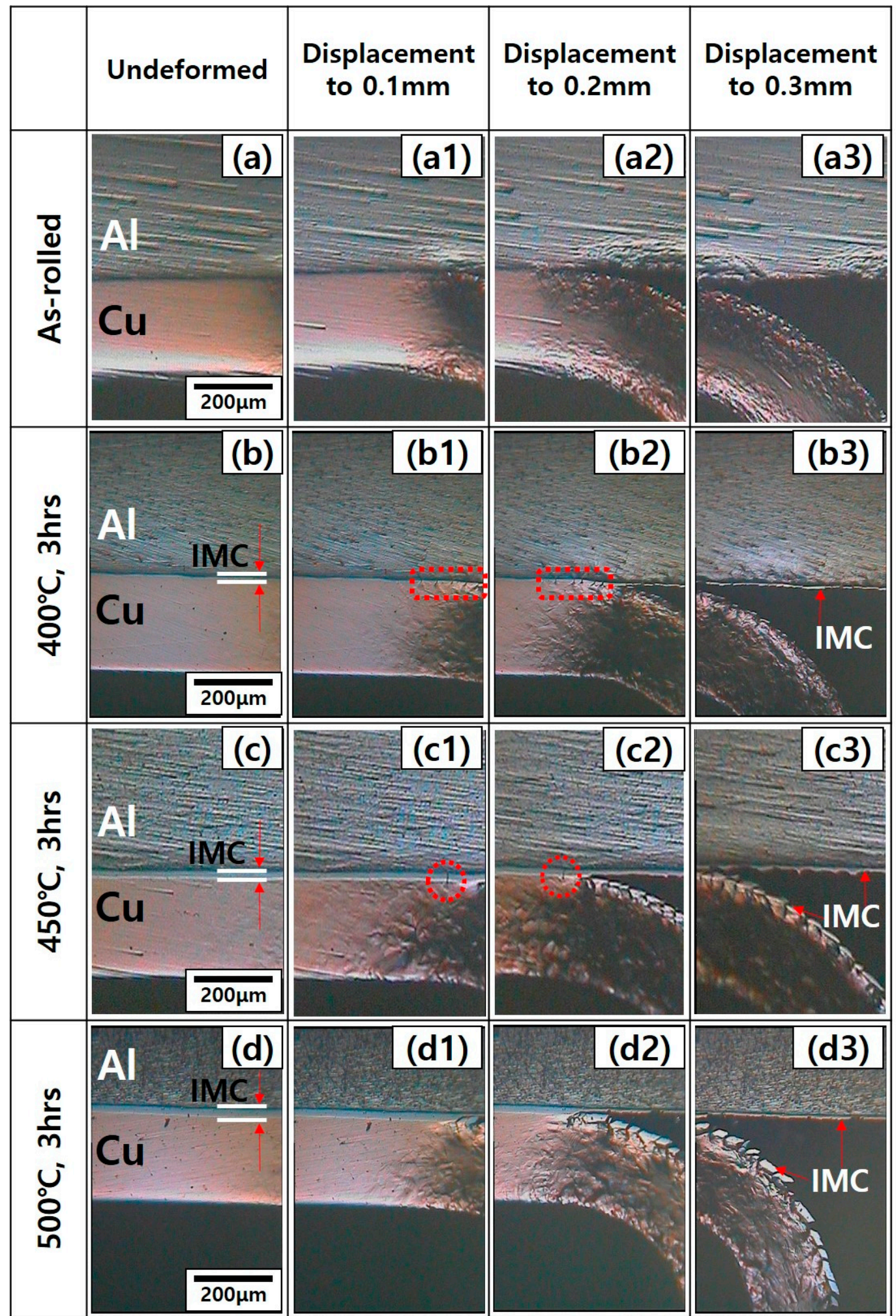

Figure 6. (a-a3) Stereoscopic microscopic images of the as-rolled specimen obtained during the peel testing at displacements of $0,0.1,0.2$, and $0.3 \mathrm{~mm}$, respectively. (b-b3) Stereoscopic microscopic images of the as-rolled specimen heat-treated at $400{ }^{\circ} \mathrm{C}$ at displacements of $0,0.1,0.2$, and $0.3 \mathrm{~mm}$, respectively. (c-c3) Stereoscopic microscopic images of the as-rolled specimen heat-treated at $450{ }^{\circ} \mathrm{C}$ at displacements of $0,0.1,0.2$, and $0.3 \mathrm{~mm}$, respectively. (d-d3) Stereoscopic microscopic images of the as-rolled specimen heat-treated at $500{ }^{\circ} \mathrm{C}$ at displacements of $0,0.1,0.2$, and $0.3 \mathrm{~mm}$, respectively. 
Figure 7 shows SEM images of the $\mathrm{Cu} / \mathrm{Al}$ interface region with a major interface crack propagating along the interface for the as-rolled specimen (Figure 7a) and in the specimens that were heat-treated at a temperature range from 400 to $500{ }^{\circ} \mathrm{C}$ for $3 \mathrm{~h}$ (Figure $7 \mathrm{~b}-\mathrm{d}$ ). The SEM image of $\mathrm{Cu} / \mathrm{Al}$ interface region for the as-roll-bonded clad composite in Figure 7a does not show any noticeable serrated surface on the separated $\mathrm{Al}$ and $\mathrm{Cu}$ plate, suggesting the rather smooth separation during peeling as supported by the smooth peel strength-displacement curve in Figure 5a. The SEM image of the clad composite annealed at $400{ }^{\circ} \mathrm{C}$ (Figure $7 \mathrm{~b}$ ) shows a thin layer of the cracked IMC layer attached to the surface of separated $\mathrm{Al}$ and $\mathrm{Cu}$ plates. Vertical cracks perpendicular to the intermetallic layer were formed (indicate by a box marked with red dashed lines) ahead of the crack front of the major crack propagating along the interface line. The SEM images of the clad composite heat-treated at $450{ }^{\circ} \mathrm{C}$ (Figure $6 \mathrm{c}$ ) and $500{ }^{\circ} \mathrm{C}$ (Figure 6d) exhibit the more pronounced serrations of the cracked IMC layer on the separated $\mathrm{Cu}$ plate due to the thicker intermetallic layer than that at $400{ }^{\circ} \mathrm{C}$. The depth of the serrated surface on the separated $\mathrm{Cu}$ plate increased with increase of heat treatment temperature. It is noted that the amplitude of serration in the peel strength-displacement curve in Figure $5 \mathrm{~b}$ increased with increase of heat treatment temperature.
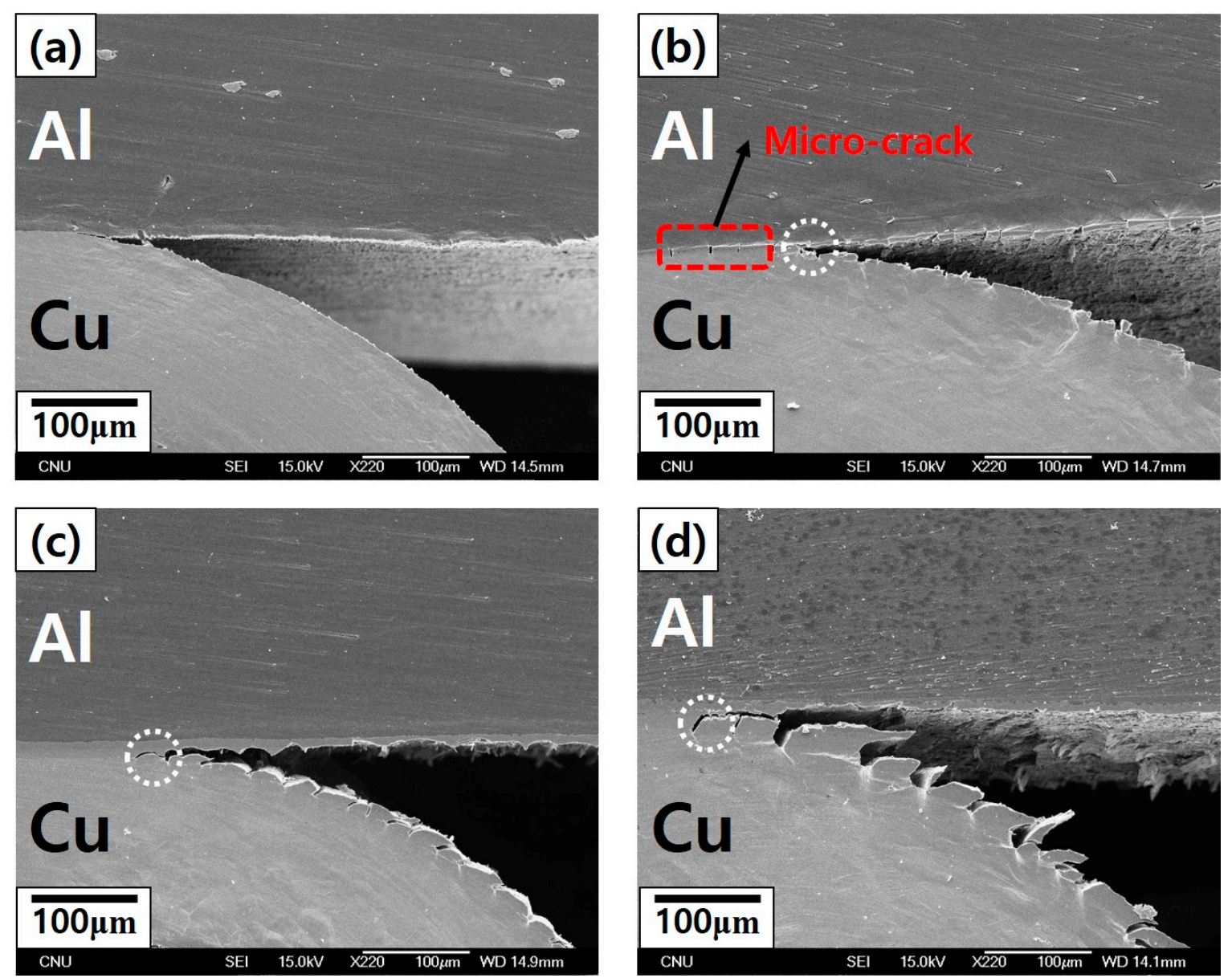

Figure 7. SEM images of the $\mathrm{Cu} / \mathrm{Al}$ interface region with a major interface crack propagating along the interface for the as-rolled specimen (a), and those heat-treated at $400{ }^{\circ} \mathrm{C}(\mathbf{b}), 450{ }^{\circ} \mathrm{C}(\mathbf{c})$, and $500{ }^{\circ} \mathrm{C}(\mathrm{d})$ for $3 \mathrm{~h}$.

In order to investigate the crack path during the peel tests, the IMC layer with the propagating crack was examined using EBSD analyses. Figures 8-10 exhibit SEM (a) and EBSD (b-g) images of the interface region in the vicinity of the tip of the propagating crack along the intermetallic layer for the $\mathrm{Cu} / \mathrm{Al} / \mathrm{Cu}$ composite plate heat-treated at $400{ }^{\circ} \mathrm{C}$ (Figure 8), $450{ }^{\circ} \mathrm{C}$ (Figure 9), and $500{ }^{\circ} \mathrm{C}$ (Figure 10). 
One interesting observation is the presence of thin $\mathrm{Cu}$ layer with fine-grained $(1.5-2 \mu \mathrm{m})$ structure above the $\mathrm{Cu}$ matrix with large grains (Figures $8 \mathrm{~d}, 9 \mathrm{~d}$ and $10 \mathrm{~d}$ ). The thin $\mathrm{Cu}$ layer with fine-grained $(1.5-2 \mu \mathrm{m})$ structure was suggested to be caused by diffusion-induced recrystallization (DIR) [28,31]. Generation or emission of dislocations caused by the lattice distortion due to the diffusion of $\mathrm{Al}$ into $\mathrm{Cu}$ [28] and/or by violent mass from $\mathrm{Al}$ to $\mathrm{Cu}$ due to concentration gradient [31] is known to induce dynamic recrystallization in the thin interface region.
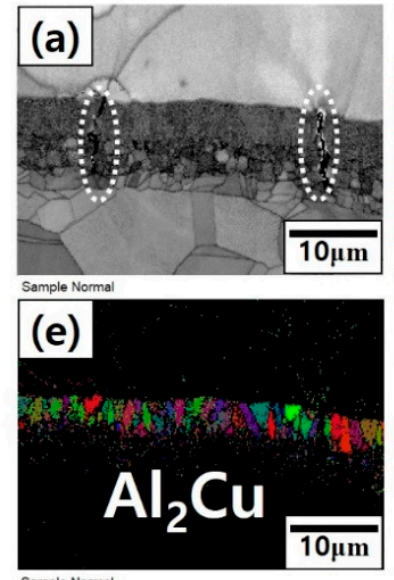
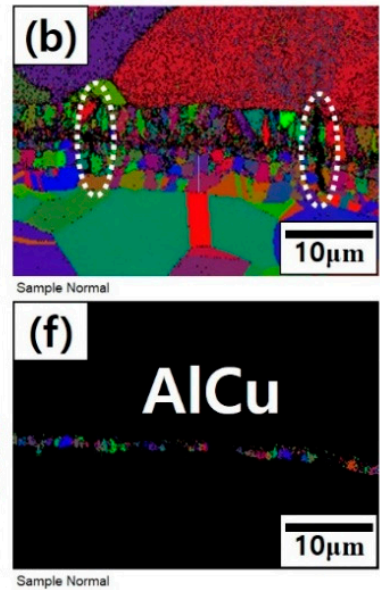
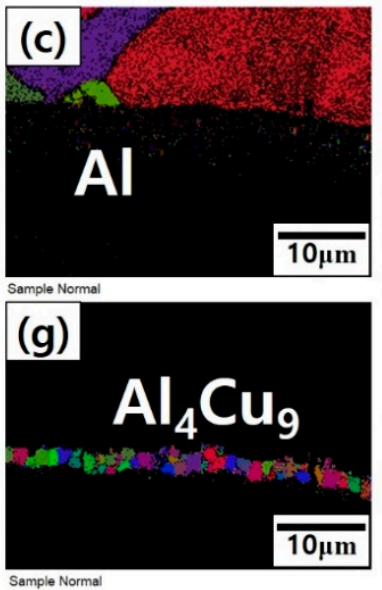

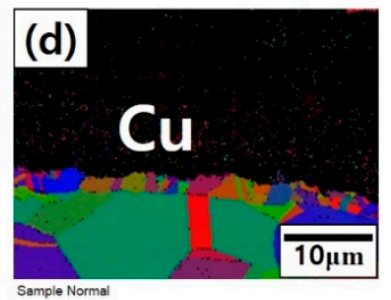

Sample Normal

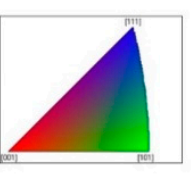

Figure 8. SEM (a) and electron backscatter diffraction (EBSD) (b-g) images of the interface region in the vicinity of the tip of the propagating crack along the intermetallic layer for the $\mathrm{Cu} / \mathrm{Al} / \mathrm{Cu}$ composite plate heat-treated at $400{ }^{\circ} \mathrm{C}$ : (a) image quality map, (b) orientation map of all phases, $(\mathbf{c}-\mathbf{g})$ orientation maps of individual phases in the order of $\mathrm{Al}, \mathrm{Cu}, \mathrm{Al}_{2} \mathrm{Cu}, \mathrm{AlCu}$, and $\mathrm{Al}_{4} \mathrm{Cu}_{9}$.
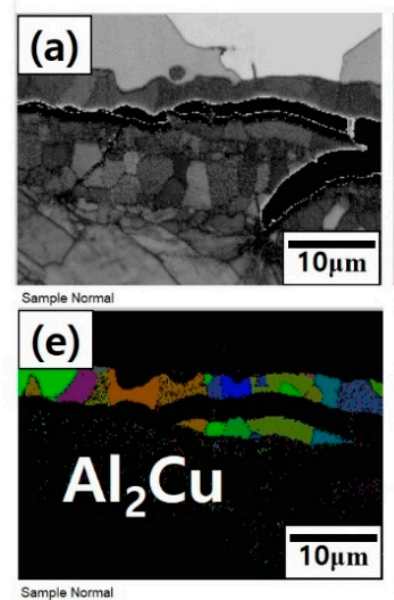
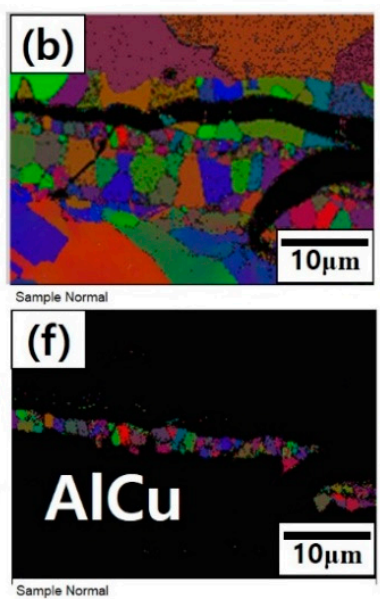
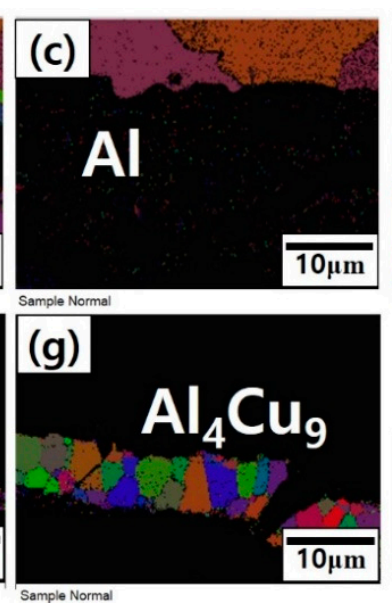

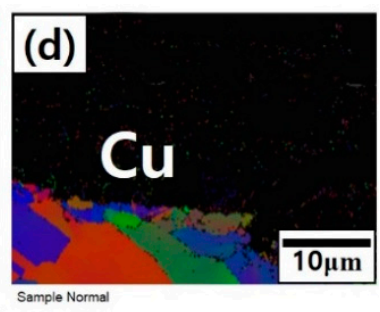

Sample Normal

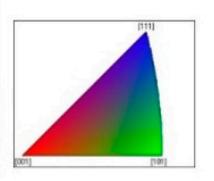

Figure 9. SEM (a) and EBSD (b-g) images of the interface region in the vicinity of the tip of the propagating crack along the intermetallic layer for the $\mathrm{Cu} / \mathrm{Al} / \mathrm{Cu}$ composite plate heat-treated at $450{ }^{\circ} \mathrm{C}$ : (a) image quality map; (b) orientation map of all phases; (c-g) orientation maps of individual phases in the order of $\mathrm{Al}, \mathrm{Cu}, \mathrm{Al}_{2} \mathrm{Cu}, \mathrm{AlCu}$, and $\mathrm{Al}_{4} \mathrm{Cu}_{9}$.

It is apparent that the major crack parallel to the interface propagated through the IMC layer, mostly along the $\mathrm{Al}_{2} \mathrm{Cu} / \mathrm{AlCu}$ boundary. Note that vertical cracks (enclosed by white circles) also developed through the intermetallic layer. The intermetallic layers of $\mathrm{Al}_{2} \mathrm{Cu}$ and $\mathrm{Al}_{4} \mathrm{Cu}_{9}$ grew thicker than that of $\mathrm{AlCu}$ in the specimen heat-treated at $450{ }^{\circ} \mathrm{C}$, as shown in Figure 9. The cracks parallel to the interface propagated along the $\mathrm{Al}_{2} \mathrm{Cu} / \mathrm{AlCu}$ boundary or partly through the $\mathrm{Al}_{2} \mathrm{Cu}$ layer. Vertical or inclined cracks propagated through the $\mathrm{AlCu}$ and $\mathrm{Al}_{4} \mathrm{Cu}_{9}$ intermetallic layers. In the $\mathrm{Cu} / \mathrm{Al} / \mathrm{Cu}$ clad composite heat-treated at $500{ }^{\circ} \mathrm{C}$ (Figure $\left.10 \mathrm{~b}-\mathrm{g}\right)$, inclined cracks roughly perpendicular to the intermetallic layer propagated through $\mathrm{Al}_{2} \mathrm{Cu}, \mathrm{AlCu}$, and $\mathrm{Al}_{4} \mathrm{Cu}_{9}$ in front of the major crack propagating 
along the $\mathrm{Al}_{2} \mathrm{Cu} / \mathrm{AlCu}$ boundary and often through the $\mathrm{Al}_{4} \mathrm{Cu}_{9}$ layer, because the $\mathrm{Al}_{4} \mathrm{Cu}_{9}$ intermetallic layer was thicker and more brittle after heat treatment at $500^{\circ} \mathrm{C}$. The inclined or vertical cracks stopped propagating when the crack front reached $\mathrm{Cu}$, developing slip lines and crack blunting in the ductile Cu plate.
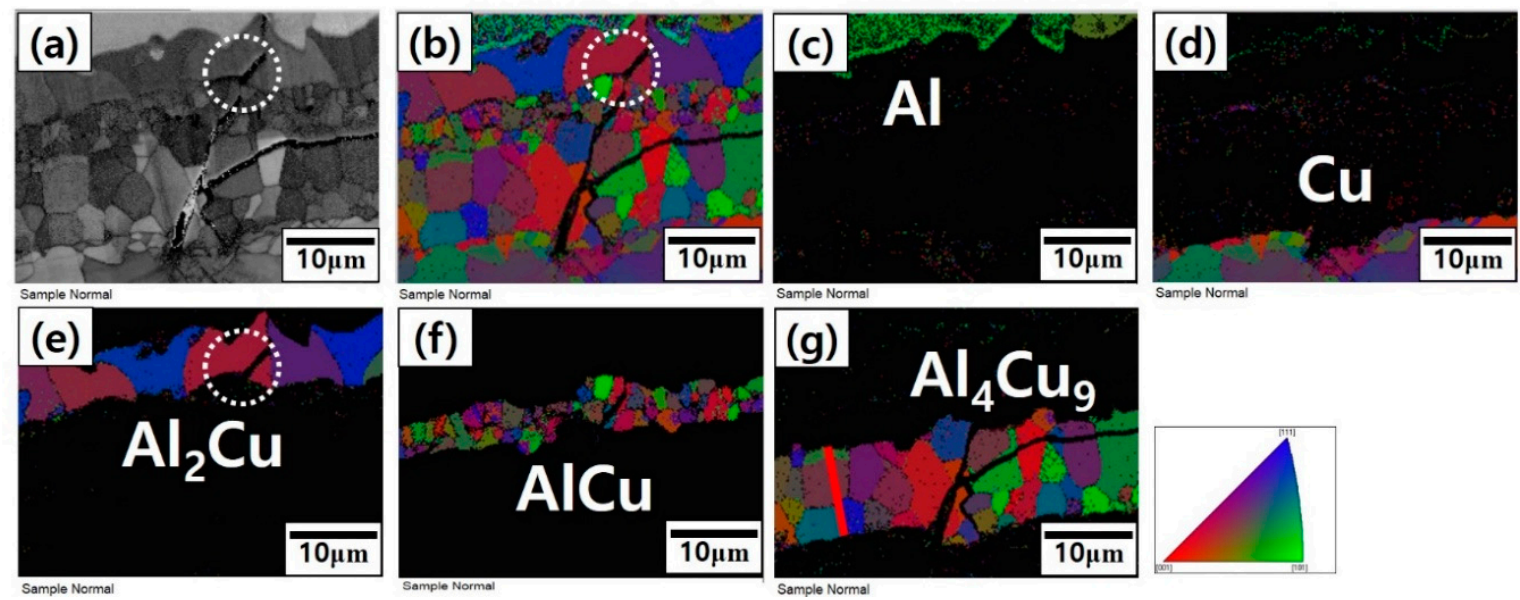

Figure 10. SEM (a) and EBSD (b-g) images of the interface region in the vicinity of the tip of the propagating crack along the intermetallic layer for the $\mathrm{Cu} / \mathrm{Al} / \mathrm{Cu}$ composite plate heat-treated at $500{ }^{\circ} \mathrm{C}$ : (a) image quality map; (b) orientation map of all phases; $(\mathbf{c}-\mathbf{g})$ orientation maps of individual phases in the order of $\mathrm{Al}, \mathrm{Cu}, \mathrm{Al}_{2} \mathrm{Cu}, \mathrm{AlCu}$, and $\mathrm{Al}_{4} \mathrm{Cu}_{9}$.

\subsection{Effect of Intermetallic Layer on Interface Toughening}

Figure 11a-1 shows the stereoscopic microscopic images (Figure 11a-f) and schematic illustration (Figure 11g-l) of the interface region at the tip of the major crack propagating along the interface during the peel test of $\mathrm{Cu} / \mathrm{Al} / \mathrm{Cu}$ clad composite heat-treated at $500{ }^{\circ} \mathrm{C}$ for $3 \mathrm{~h}$. It displays the crack generation and growth processes. The areas where the changes of crack morphology were observed are marked with white circles, and newly generated cracks are marked with thin black dotted lines in Figure 11g-1. It is apparent that the major crack propagated along the interface of $\mathrm{Al}_{2} \mathrm{Cu} / \mathrm{AlCu}$ intermetallic boundary. In Figure 11b, 11c, 11h, and 11i, an inclined crack (roughly perpendicular to the intermetallic layer) propagated through the $\mathrm{Al}_{4} \mathrm{Cu}_{9}$ layer and slip lines (marked with red lines) developed in the ductile $\mathrm{Cu}$ plate as the bending of $\mathrm{Cu}$ plate continued. It should be noted that another inclined crack started to develop as the slip lines developed in the $\mathrm{Cu}$ plate. The same process continued as the major crack propagated along the $\mathrm{Al}_{2} \mathrm{Cu} / \mathrm{AlCu}$ intermetallic boundary until complete separation.

As shown in Figures 4 and 5 the peel strength increased with heat treatment temperatures up to $300{ }^{\circ} \mathrm{C}$, but it decreased drastically after heat treatment at temperatures above $400{ }^{\circ} \mathrm{C}$. It should be noted that the intermetallic layer increased rapidly at temperatures above $300^{\circ} \mathrm{C}$. The increase of peel strength after heat treatment at 200 and $300^{\circ} \mathrm{C}$ (Figure 5) is accompanied by the increase of electrical conductivity (Figure 4). As stated, the increase of the conductivity after heat treatment at 200 and $300{ }^{\circ} \mathrm{C}$ was suggested to be caused by the enhanced interface diffusion bonding of the weakly bonded region. The enhanced bonding during heat treatment at 200 and $300{ }^{\circ} \mathrm{C}$ would also contribute to the increase of peel strength. One of the most interesting observation is that the peel strength increased with increasing annealing temperature above $400{ }^{\circ} \mathrm{C}$ after it dropped sharply after heat treatment at $400{ }^{\circ} \mathrm{C}$. Since the amplitude and wavelength of serration on the peeled-off $\mathrm{Cu}$ plate increased with increasing IMC layer thickness as shown in Figure 7 and the peel strength increased with increase of stress serrations in the peel strength-displacement curves at temperatures above $400{ }^{\circ} \mathrm{C}$ as shown in Figure 5, the variations of IMC layer thickness, inter-crack spacing (spacing between inclined cracks on the serrated surface of peeled-off $\mathrm{Cu}$ plate), and the peel strength are plotted against the heat treatment temperature in Figure 12. As shown in Figure 12, IMC thickness, inter-crack spacing of serrated surface 
of peeled-off $\mathrm{Cu}$ plate, and the peel strength all increased in parallel with increase of heat treatment temperature, supporting the correlations between these three.
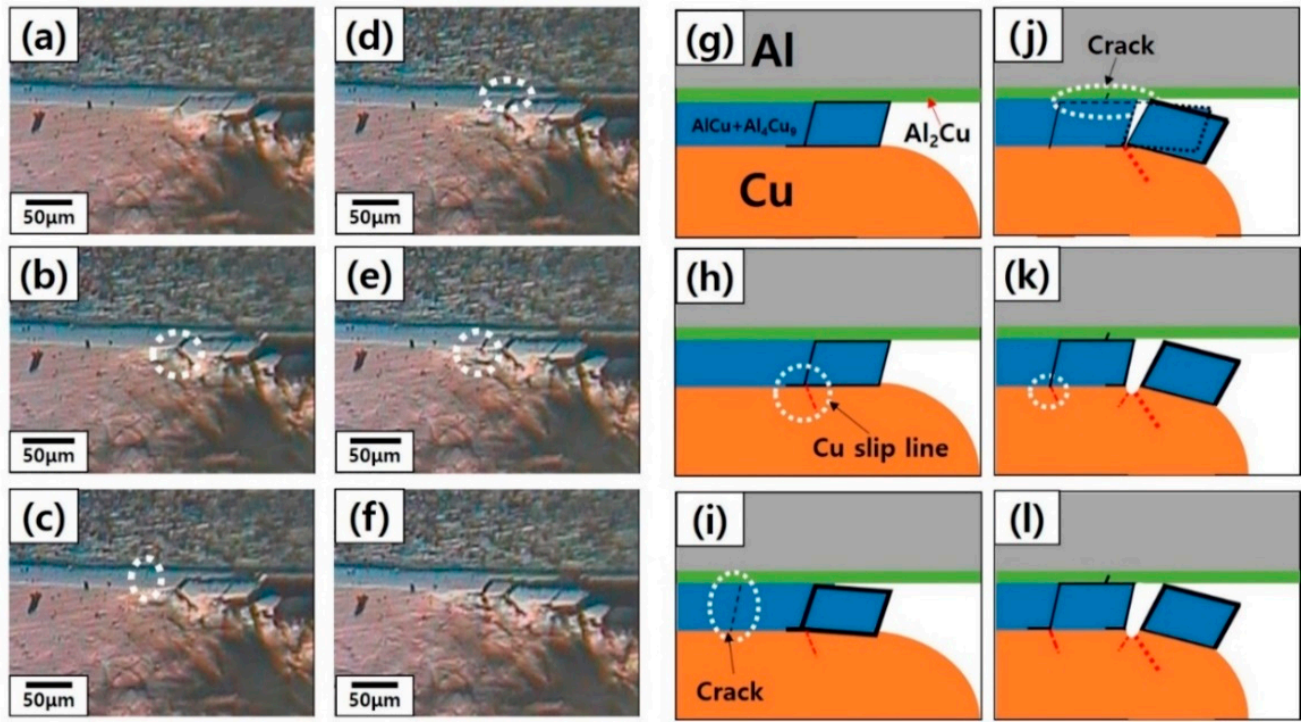

Figure 11. Stereoscopic microscopic images $(\mathbf{a}-\mathbf{f})$ and schematic illustration $(\mathbf{g}-\mathbf{l})$ of the interface region at the tip of the major crack propagating along the interface during the peel test of $\mathrm{Cu} / \mathrm{Al} / \mathrm{Cu}$ clad composite heat-treated at $500{ }^{\circ} \mathrm{C}$ for $3 \mathrm{~h}$.

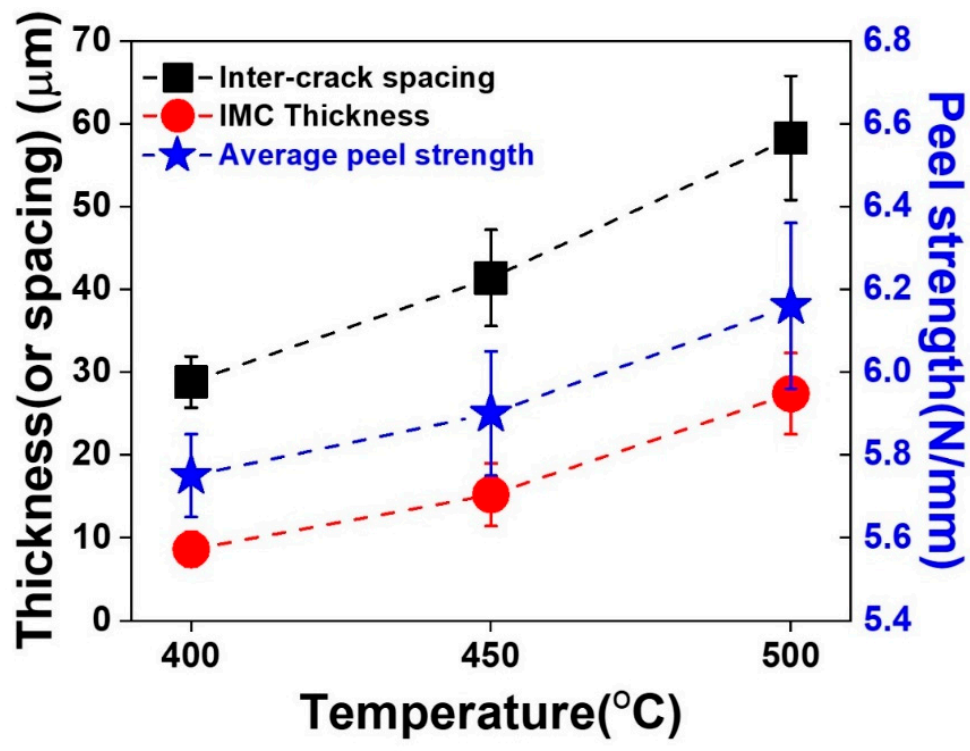

Figure 12. Variations of intermetallic compound (IMC) layer thickness, inter-crack spacing, and the peel strength as a function of heat treatment temperature.

The repetition of crack propagation along the interface and crack deflection through the intermetallic layer to the surface of $\mathrm{Cu}$ plate as an inclined crack induces the serrated surface on the peeled-off $\mathrm{Cu}$ plate. The interruption of continuous crack propagation and deviation of propagating crack away from the $\mathrm{Al}_{2} \mathrm{Cu} / \mathrm{AlCu}$ boundary toward the inclined crack would require more energy and contribute to interface toughening. Since the severity of crack deflection and total crack travel path due to crack path serration increases with increasing intermetallic layer thickness, the amplitude of peel strength serration in the peel strength-displacement relationship would increase. 
The repetitive crack deviation would increase the energy required for crack propagation, resulting in the general increase of the peel strength with increasing IMC layer thickness.

\section{Conclusions}

The influence of IMC layer thickness on the peel strength and crack propagation behaviors in the $\mathrm{Cu} / \mathrm{Al} / \mathrm{Cu}$ clad composite with modifications of interface structure were studied and the conclusions were obtained as follows:

1. The peel strengths of the $\mathrm{Cu} / \mathrm{Al} / \mathrm{Cu}$ clad annealed at $200{ }^{\circ} \mathrm{C}(9.05 \mathrm{~N} / \mathrm{mm})$ and $300{ }^{\circ} \mathrm{C}(9.01 \mathrm{~N} / \mathrm{mm})$ were higher than that of the as-rolled specimen $(7.8 \mathrm{~N} / \mathrm{mm})$. Interface toughening of $\mathrm{Cu} / \mathrm{Al} / \mathrm{Cu}$ was achieved by forming thin discontinuous intermetallic layers through enhanced the interface diffusion bonding of a weakly roll-bonded region by lower-temperature heat treatment at $200-300^{\circ} \mathrm{C}$.

2. The increase of peel strength in the $\mathrm{Cu} / \mathrm{Al} / \mathrm{Cu}$ composite in the presence of thin discontinuous IMCs with heat treatment at $200-300{ }^{\circ} \mathrm{C}$ was accompanied by the increase of electrical conductivity from 65.3\% IACS (International Annealed Copper Standard) to $66.8 \%$ IACS. The increase of the conductivity after heat treatment at 200 and $300{ }^{\circ} \mathrm{C}$ is thought to be due to the enhanced interface diffusion bonding of the weakly bonded region. As the IMC layer thickness increased with temperatures above $400{ }^{\circ} \mathrm{C}$, the conductivity dropped rapidly because of the rapid growth of intermetallic layer.

3. The peel strength decreased noticeably after annealing at $400{ }^{\circ} \mathrm{C}(5.75 \mathrm{~N} / \mathrm{mm})$ because of the thick brittle intermetallic layers and stress levels of the curves increased as the annealing temperature further increased from 400 to $500{ }^{\circ} \mathrm{C}$. The increased peel strength levels of $\mathrm{Cu} / \mathrm{Al} / \mathrm{Cu}$ clad heat-treated at $450{ }^{\circ} \mathrm{C}(5.91 \mathrm{~N} / \mathrm{mm})$ and $500{ }^{\circ} \mathrm{C}(6.16 \mathrm{~N} / \mathrm{mm})$ compared to that heat-treated at $400{ }^{\circ} \mathrm{C}$ were accompanied by pronounced serrations of the peel strength-displacement curves.

4. The major crack along the interface propagated through the IMC layer, mostly along the $\mathrm{Al}_{2} \mathrm{Cu} / \mathrm{AlCu}$ boundary with some inclined cracks, propagated through the $\mathrm{AlCu}$ and $\mathrm{Al}_{4} \mathrm{Cu}_{9}$ intermetallic layers. The interruption of continuous crack propagation and deflection of propagating crack away from $\mathrm{Al}_{2} \mathrm{Cu} / \mathrm{AlCu}$ boundary toward the inclined crack would require more energy and contribute to interface toughening.

5. Peel strength, intermetallic layer thickness, and inter-crack spacing of the IMC layer on the peeled-off $\mathrm{Cu}$ plate increased in parallel with increase of heat treatment temperature, supporting the correlations between peel strength and the intermetallic layer in the presence of thick continuous IMC layers after heat treatment between 400 and $500{ }^{\circ} \mathrm{C}$.

Supplementary Materials: The following are available online at http://www.mdpi.com/2075-4701/9/11/1155/s1, Video S1: Interface cracking during the peel test of as-roll-bonded $\mathrm{Cu} / \mathrm{Al} / \mathrm{Cu}$, Video S2: Interface cracking during the peel test of $\mathrm{Cu} / \mathrm{Al} / \mathrm{Cu}$ heat-treated at $400{ }^{\circ} \mathrm{C}$, Video S3: Interface cracking during the peel test of $\mathrm{Cu} / \mathrm{Al} / \mathrm{Cu}$ heat-treated at $450{ }^{\circ} \mathrm{C}$, Video S4: Interface cracking during the peel test of $\mathrm{Cu} / \mathrm{Al} / \mathrm{Cu}$ heat-treated at $500{ }^{\circ} \mathrm{C}$.

Author Contributions: Conceptualization, S.I.H.; methodology, Y.K.K.; investigation, Y.K.K.; writing and editing, Y.K.K. and S.I.H; visualization, Y.K.K.; supervision, S.I.H.

Funding: This research was funded through the 3rd phase of the Fundamental R\&D Programs for Core Technology of Materials (K_G011005095105) from by the Ministry of Trade, industry and Energy (MOTIE), South Korea (2018-2019).

Conflicts of Interest: The authors declare no conflicts of interest.

\section{References}

1. Burger, G.; Gupta, A.; Jeffrey, P.; Lloyd, D. Microstructural control of aluminum sheet used in automotive applications. Mater. Charact. 1995, 35, 23-39. [CrossRef]

2. Cole, G.; Sherman, A. Light weight materials for automotive applications. Mater. Charact. 1995, 35, 3-9. [CrossRef] 
3. Moisy, F.; Gueydan, A.; Sauvage, X.; Guillet, A.; Keller, C.; Guilmeau, E.; Hug, E. Influence of intermetallic compounds on the electrical resistivity of architectured copper clad aluminum composites elaborated by a restacking drawing method. Mater. Des. 2018, 155, 366-374. [CrossRef]

4. Duan, J.Q.; Quadir, M.Z.; Xu, W.; Kong, C.; Ferry, M. Texture balancing in a fcc/bcc multilayered composite produced by accumulative roll bonding. Acta Mater. 2017, 123, 11-23. [CrossRef]

5. Manesh, H.D.; Taheri, A.K. Bond strength and formability of an aluminum-clad steel sheet. J. Alloys Compd. 2003, 361, 138-143. [CrossRef]

6. Ha, J.S.; Hong, S.I. Deformation and fracture of Ti/439 stainless steel clad composite at intermediate temperatures. Mater. Sci. Eng. A 2016, 651, 805-809. [CrossRef]

7. Xiao, H.; Qi, Z.; Yu, C.; Xu, C. Preparation and properties for Ti/Al clad plates generated by differential temperature rolling. J. Mater. Process. Technol. 2017, 249, 285-290. [CrossRef]

8. Kim, Y.K.; Hong, S.I. Influence of interface structure and stress distribution on fracture and mechanical performance of STS439/Al1050/STS304 clad composite. Mater. Sci. Eng. A 2019, 749, 35-47. [CrossRef]

9. Wang, S.; Liu, B.X.; Chen, C.X.; Feng, J.H.; Yin, F.X. Microstructure, mechanical properties and interface bonding mechanism of hot-rolled stainless steel clad plates at different rolling reduction ratios. J. Alloys Compd. 2018, 766, 517-526. [CrossRef]

10. Kim, I.-K.; Hong, S.I. Effect of component layer thickness on the bending behaviors of roll-bonded tri-layered $\mathrm{Mg} / \mathrm{Al} / \mathrm{STS}$ clad composites. Mater. Des. 2013, 49, 935-944. [CrossRef]

11. Kim, I.-K.; Hong, S.I. Roll-bonded tri-layered Mg/Al/stainless steel clad composites and their deformation and fracture behavior. Metall. Mater. Trans. A 2013, 44, 3890-3900. [CrossRef]

12. Kim, I.-K.; Hong, S.I. Mechanochemical joining in cold roll-cladding of tri-layered $\mathrm{Cu} / \mathrm{Al} / \mathrm{Cu}$ composite and the interface cracking behavior. Mater. Des. 2014, 57, 625-631. [CrossRef]

13. Jin, J.Y.; Hong, S.I. Effect of heat treatment on tensile deformation characteristics and properties of Al3003/STS439 clad composite. Mater. Sci. Eng. A 2014, 596, 1-8. [CrossRef]

14. Kocich, R.; Kunčická, L.; Král, P.; Strunz, P. Characterization of innovative rotary swaged Cu-Al clad composite wire conductors. Mater. Des. 2018, 160, 828-835. [CrossRef]

15. Kim, W.N.; Hong, S.I. Interactive deformation and enhanced ductility of tri-layered $\mathrm{Cu} / \mathrm{Al} / \mathrm{Cu}$ clad composite. Mater. Sci. Eng. A 2016, 651, 976-986. [CrossRef]

16. Kim, I.-K.; Hong, S.I. Effect of heat treatment on the bending behavior of tri-layered $\mathrm{Cu} / \mathrm{Al} / \mathrm{Cu}$ composite plates. Mater. Des. 2013, 47, 590-598. [CrossRef]

17. Kocich, R.; Macháčková, A.; Kunčická, L.; Fojtík, F. Fabrication and characterization of cold-swaged multilayered Al-Cu clad composites. Mater. Des. 2015, 71, 36-47. [CrossRef]

18. Kim, H.; Kang, G.T.; Hong, S.I. Thermomechanical processing and roll bonding of tri-layered $\mathrm{Cu}-\mathrm{Ni}-\mathrm{Zn} / \mathrm{Cu}-\mathrm{Cr} / \mathrm{Cu}-\mathrm{Ni}-\mathrm{Zn}$ composite. Metall. Mater. Trans. A 2016, 47, 2267-2276. [CrossRef]

19. Hong, S.I.; Hill, M.A. Mechanical stability and electrical conductivity of $\mathrm{Cu}-\mathrm{Ag}$ filamentary microcomposites. Mater. Sci. Eng. A 1999, 264, 151-158. [CrossRef]

20. Wang, Y.; Song, R.; Yanagimoto, J.; Li, H. Effect of heat treatment on bonding mechanism and mechanical properties of high strength $\mathrm{Cu} / \mathrm{Al} / \mathrm{Cu}$ clad composite. J. Alloys Compd. 2019, 801, 573-580. [CrossRef]

21. Gueydan, A.; Domengès, B.; Hug, E. Study of the intermetallic growth in copper-clad aluminum wires after thermal aging. Intermetallics 2014, 50, 34-42. [CrossRef]

22. Mathew, R.T.; Mule, D.; Balasubramaniam, K.R.; Prasad, M.J.N.V. Microstructure and tensile behavior of $\mathrm{Cu} / \mathrm{Sn} / \mathrm{Zn}$ trimetallic claddings produced by roll bonding process. J. Alloys Compd. 2017, 725, 818-823. [CrossRef]

23. Abedi, R.; Akbarzadeh, A. Bond strength and mechanical properties of three-layered St/AZ31/St composite fabricated by roll bonding. Mater. Des. 2015, 88, 880-888. [CrossRef]

24. Tolaminejad, B.; Hoseini Athar, M.M.; Arabi, H.; Karimi Taheri, A. Enhanced grain refinement of commercial pure copper using the ECAE of Al-Cu-Al tri-layer composite. Eng. Sci. Tech. Int. J. 2016, 19, 254-259. [CrossRef]

25. Eslami, P.; Karimi Taheri, A.; Zebardast, M. A comparison between cold-welded and diffusion-bonded Al/Cu bimetallic rods produced by ECAE process. J. Mater. Eng. Perform. 2013, 22, 3014-3023. [CrossRef]

26. Shiran, M.K.G.; Khalaj, G.; Pouraliakbar, H.; Jandaghi, M.R.; Dehnavi, A.S.; Bakhtiari, H. Multilayer Cu/Al/Cu explosive welded joints: Characterizing heat treatment effect on the interface microstructure and mechanical properties. J. Manuf. Processes 2018, 35, 657-663. [CrossRef] 
27. Xu, X.; Mi, G.; Chen, L.; Xiong, L.; Jiang, P.; Shao, X.; Wang, C. Research on microstructures and properties of Inconel 625 coatings obtained by laser cladding with wire. J. Alloys Compd. 2017, 715, 362-373. [CrossRef]

28. Gueydan, A.; Hug, E. Secondary creep stage behavior of copper-clad aluminum thin wires submitted to a moderate temperature level. Mater. Sci. Eng. A 2018, 709, 134-138. [CrossRef]

29. Okamoto, H.; Schlesinger, M.; Mueller, E. ASM handbook volume 3: Alloy phase diagrams; ASM International: Materials Park, OH, USA, 2016; p. 285.

30. Xu, H.; Liu, C.; Silberschmidt, V.V.; Pramana, S.S.; White, T.J.; Chen, Z.; Acoff, V.L. Behavior of aluminum oxide, intermetallics and voids in $\mathrm{Cu}-\mathrm{Al}$ wire bonds. Acta Mater. 2011, 59, 5661-5673. [CrossRef]

31. den Broeder, F.J.A. Diffusion-induced grain boundary migration and recrystallization, exemplified by the system Cu-Zn. Thin Solid Films 1985, 124, 135-148. [CrossRef]

(C) 2019 by the authors. Licensee MDPI, Basel, Switzerland. This article is an open access article distributed under the terms and conditions of the Creative Commons Attribution (CC BY) license (http://creativecommons.org/licenses/by/4.0/). 